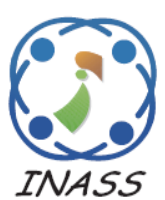

\title{
The Operational, Economic and Environmental Benefits of Returnable Packaging Under Various Reverse Logistics Arrangements
}

\author{
Nophanut Katephap ${ }^{1^{*}}$ \\ Sunpasit Limnararat ${ }^{1}$ \\ ${ }^{1}$ Faculty of Engineering, King Mongkut's Institute of Technology Ladkrabang, \\ Chalongkrung Road, Ladkrabang, Bangkok 10520, Thailand \\ * Corresponding author's Email: 57601079@kmitl.ac.th
}

\begin{abstract}
This research investigates the operational, economic and environmental advantages of the returnable packaging under various reverse logistics arrangements, in relation to the disposable packaging. The business under study is a Thai manufacturer and exporter of automotive parts with the trading partners in the Philippines and Vietnam. In the study, a switch was made from the currently disposable packaging to the standardized returnable packaging under three reverse logistics arrangements: the single-, round- and multi-trip arrangements. Due to the large initial investment associated with the returnable packaging, a mathematical model was proposed to calculate the total effective packaging cost. The research findings revealed that the multi-trip reverse logistics arrangement was most operationally and environmentally viable, with the largest total packaging cost reduction and packaging waste reduction of $61 \%$ and $68 \%$, relative to the disposable packaging. Meanwhile, the single-trip reverse logistics arrangement was most favorable economically due to its shortest payback period of 0.33 year. Moreover, the life cycle assessment (LCA) was applied to the disposable and returnable packaging to evaluate the environmental impacts throughout their lifetime. The LCA results validate the more environmentally-friendly nature of the returnable packaging.
\end{abstract}

Keywords: Returnable packaging, Reverse logistics, Operational benefit, Economic benefit, Environmental benefit, Life cycle assessment.

\section{Introduction}

With growing concerns over climate change and global warming, businesses are forced to adopt a more environmentally-friendly operational practice to avoid a public backlash against their current environmentally-hostile business practices. According to [1-2], reverse logistics could effectively address the environmental concerns and at the same time contribute to the increased competitiveness and greater marketing share. [3-4] documented that, despite its enormous burden on the natural resources and the harmful waste, the disposable packaging is still ubiquitous; and that the returnable packaging could reduce the packaging waste and provide the cost savings to businesses.

According to [5-6], forward logistics refers to the supply chain management from the node of origin to the node of consumption, while reverse logistics is that from the node of consumption to the node of origin. Specifically, forward logistics starts with the transformation of new or fresh materials through manufacturing into the finished products which are then transferred to the retailers to resell to the customers where the process is terminated. On the other hand, in reverse logistics, once the products are resold or consumed, the packaging or containers are returned to the original node for the subsequent use.

The recent evolution in logistics has led to the closed-loop supply chain, where the forward and reverse logistics arrangements are integrated. According to [7], a typical closed-loop supply chain contains both forward (supplying raw materials, processing, assembling, distributing/retailing, and consuming) and reverse (repairing, reconditioning, 
remanufacturing, recycling, and disposing) supply chain processes.

According to [8-9], the adoption of reverse logistics is subject to a number of factors, including the packaging lifetime, the reduced cycle lead time, the logistics cost savings, and the lower environmental impacts. Specifically, [10] investigated the relationship between the life cycle of the post-consumption packaging and the return rate and reported that the packaging return rate was positively correlated with the average packaging lifetime and the damage to the contents.

[11] studied the use of reverse logistics with the printer products and identified several activities that contributed to the longer cycle lead time. However, [12] proposed the streamlining of transportation to shorten the cycle lead time. According to [13-15], the environmental impacts could be minimized through the increased recovery rate of the returned packaging and through the disposal of packaging only if its recovery is definitely impossible.

The choice between the disposable and returnable packaging is partly influenced by the economic value of the emptied packaging in the reverse flow. According to [16], the packaging standardization contributed to the lower transportation cost during the reverse flow as the weight and required space for the emptied packaging were considerably reduced. Specifically, the standardized and lightweight packaging material contributed to the lower shipment cost, especially in the case of returnable packaging.

[17-19] noted that the mode of shipment and return played a crucial role in the successful implementation of returned packaging as the unproductive cycle lead time could be eliminated. According to [20], like the disposable packaging, the returnable packaging requires an initial fabrication cost (i.e. investment cost), transportation cost and storage cost; but, unlike the disposable packaging, the returnable packaging reduces the packaging waste at the buyer's site and could be redeployed as the secondary material.

[21] investigated the returnable packaging system of Canada Post and proposed a mathematical model to estimate the emptied returnable packaging to match the demand without an inventory surplus or delivery delay. [22] reported several benefits of a switch from the disposable packaging to returnable packaging, e.g. the reduced burden on the natural resources and the cost savings. [23] studied a Brazilian manufacturer that supplied goods to the U.K. market and had recently switched from the disposable to returnable packaging. The result showed that the switch reduced the packaging waste at the buyer's site. However, [24] argued that the returnable packaging system commonly used in the automotive industry was not always preferable in terms of sustainability due to the need to return the returnable packaging over long distances; and that the specific characteristics of the materials required to fabricate the returnables may lead to situations where the disposables are operationally preferable.

On the economic front, the costs of packaging, cleaning and repairing and the packaging lifetime played an influential role in the financial payment period of the automotive industry ([25]). According to [26], the returnable packaging considerably lowered the costs associated with the routine packaging purchase and disposal, but the scheme required a large initial investment. [24,27-30] documented that the inland transportation and ocean freight costs were the main considerations in the deployment of returnable packaging; but failed to discuss the mathematic model used in the cost calculation.

On the environmental front, [31] applied the life cycle assessment (LCA) method to evaluating the environmental impacts of the returnable food packaging and noted that both the lower environmental impacts and the improved packaging performance could be achieved with the returnable packaging. [32] proposed an LCA-based method to identify the environmentally-friendly techniques for the canned anchovy production and delivery. [33] conducted the environmental impact analysis using the LCA method of wood pallet production. [34] studied the environmental impacts of the bottling, packaging, distribution and waste disposal treatment of the wine production in Italy using the LCA analysis and proposed ways to decrease the environmental impacts.

In fact, the aforementioned publications are centered around the switch from the disposable to return packaging under the single-trip arrangement. In addition, despite the discussion on the cost reduction and payback period, none of the studies has proposed a mathematical model for the total packaging cost. This current research thus investigated the operational, economic and environmental benefits of the returnable packaging under three reverse logistics arrangements (the single-, round- and multi-trip arrangements) of a Thailand-based auto-parts manufacturer and exporter. In addition, a mathematical model for calculating the total packaging cost was proposed. Moreover, the life cycle assessment (LCA) was applied to the disposable and returnable packaging to evaluate their respective environmental impacts throughout their lifetime. The environmental impact 
categories included the abiotic depletion potential (ADP), acidification potential (AP), photochemical ozone creation potential (POCP), eutrophication potential (EP), ozone layer depletion potential (ODP) and global warming potential (GWP).

\section{Research methodology and data collection}

The study first investigated the disposable packaging practice and then examined the three reverse logistics arrangements of returnable packaging: the single-, round- and multi-trip arrangements. A comprehensive mathematical model for determining the total packaging cost was presented, and the payback periods under the disposable packaging and the three reverse logistics arrangements calculated and compared.

In the automotive parts exportation, the packaging (60\%), transportation $(30 \%)$ and labor $(10 \%)$ costs (excluding the parts products) constitute the entire exportation cost. Since the packaging cost represents the largest proportion of the total exportation cost, it is the focus of this research. Categorically, the packaging cost was made up of $70 \%$ for the metallic frame, $28 \%$ the carton box and $2 \%$ the documentation (Source: Toyota Motor Thailand).

A further breakdown of the metallic frame by the adoption ratio (popularity) included the S1-type (88\%), S2-type (8\%) S4-type (3\%) and other (1\%). Because of the highest adoption ratio of the S1-type metallic frame, it is the focus of this research with regard to the packaging cost for exportation of the automotive parts. In fact, the S1-type metallic frame is commonly used for shipping a variety of automotive parts to eliminate the need to carry many types of packaging (i.e. the common packaging practice).

\section{Disposable and returnable packaging under different logistics arrangements}

\section{Disposable Packaging}

Currently, the automotive parts were shipped in the disposable packaging. Specifically, one pallet of goods under the disposable packaging arrangement required one set of the $\mathrm{S} 1$ metallic frame (disposable, $55 \mathrm{Kg}$ in weight), four carton pads, five meters of the kola tape and one paper identification label.

Fig. 1 illustrates the assembly of the disposable packaging in which four carton pads retained boxes of the automotive parts inside the S1 metallic frame, and the kola tape secured the carton pads to the metallic frame.

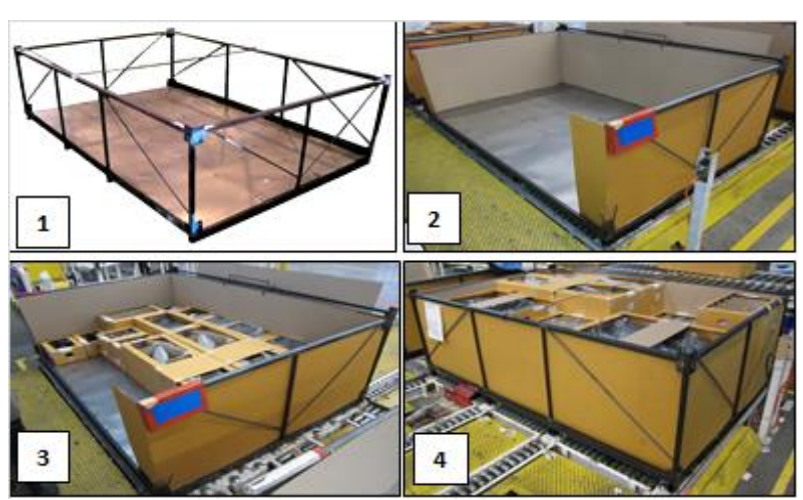

Figure.1 The assembly of the disposable packaging (Source: Toyota Motor Thailand)

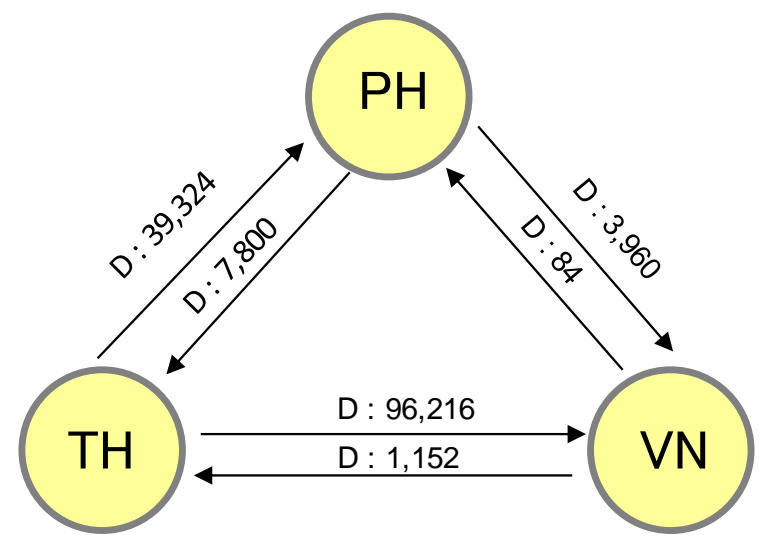

Figure.2 The annual disposable packaging requirements, where $\mathrm{TH}, \mathrm{PH}$ and VN denote Thailand, the Philippines and Vietnam; D is the disposable packaging; and the symbol $\rightarrow$ denotes the flow of the auto-parts and packaging (Source: Toyota Motor Thailand).

Fig. 2 illustrates the annual requirements of the disposable packaging of the three countries under study: Thailand $(\mathrm{TH})$, the Philippines $(\mathrm{PH})$ and Vietnam (VN). In the figure, TH shipped 39,324 units of the disposable packaging to $\mathrm{PH}$, while 7,800 and 3,960 units of the disposable packaging were required by $\mathrm{PH}$ to ship goods to $\mathrm{TH}$ and $\mathrm{VN}$. The unused units were scrapped at the buyer's site (the Philippines). In addition, TH shipped 96,216 units of the disposable packaging to $\mathrm{VN}$, while only 1,152 and 84 units of the disposable packaging were redeployed by VN to ship goods to $\mathrm{TH}$ and $\mathrm{PH}$. The unused units were scrapped at the buyer's site (Vietnam). Thus, under the current disposable packaging arrangement, the overall disposable packaging requirement was 135,540 $(39,324+96,216)$ units (Table 1).

Returnable Packaging under Single-Trip Arrangement

Following the adoption of the reverse logistics 


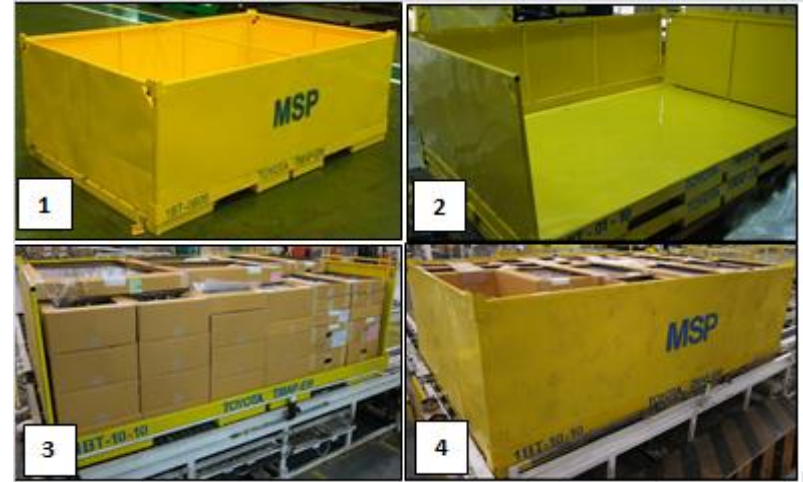

Figure.3 The structurally strengthened returnable packaging (Source: Toyota Motor Thailand)

scheme, the S1-type metallic frame was strengthened to prolong its lifetime to as long as 6 years, while the frame dimensions remained unchanged. The steel plates were used in place of the carton pads. Specifically, the materials required for the returnable packaging included one set of the structurally strengthened S1 metallic frame and four steel plates (returnable, $105 \mathrm{Kg}$ in weight) and one paper identification label.

Fig. 3 illustrates the structurally strengthened returnable packaging for the automotive parts shipment. In the assembly, the carton pads and the kola tape were no longer required. Upon completion, boxes of the auto parts were arranged one-by-one and an identification label attached on the outside.

Fig. 4 illustrates the annual requirements of the returnable packaging under the single-trip arrangement by the three countries. Under the single-trip arrangement, a certain quantity of the disposable packaging (16,895 units) remained as required by the Philippines $(\mathrm{PH})$ and Vietnam (VN). In the figure, $\mathrm{TH}$ shipped 15,288 and 24,036 units of the disposable and returnable packaging to $\mathrm{PH}$, while $\mathrm{PH}$ redeployed 7,800 and 3,960 units of the disposable packaging to ship goods to $\mathrm{TH}$ and VN.

In addition, $\mathrm{TH}$ shipped 1,607 and 94,609 units of the disposable and returnable packaging to $\mathrm{VN}$, while VN redeployed 1,152 and 84 units of the disposable packaging to send goods to $\mathrm{TH}$ and $\mathrm{PH}$. The unused disposable packaging at the buyer's site would be scraped, while the unused returnable packaging were returned to $\mathrm{TH}$. Thus, under the single-trip returnable packaging arrangement, the requirements for the disposable and returnable packaging were $16,895(15,288+1,607)$ and 118,645 $(24,036+94,609)$ units (Table 1).

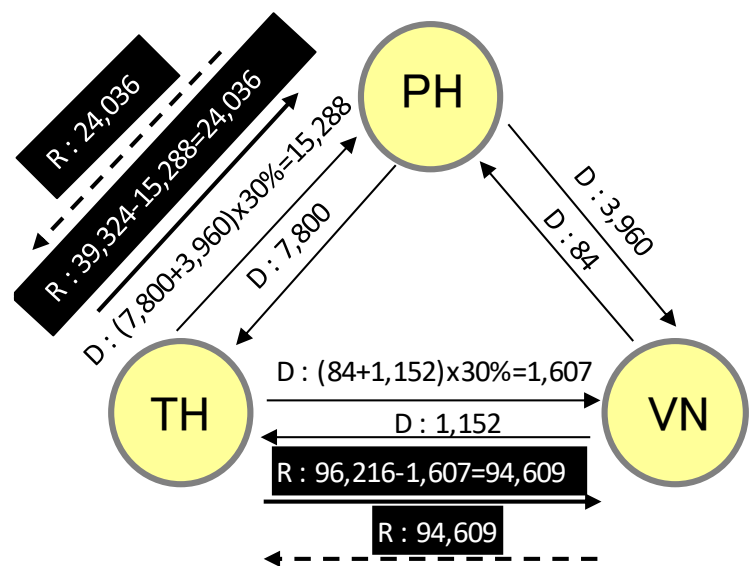

Figure.4 The annual returnable packaging requirements under the single-trip arrangement, where TH, PH and VN denote Thailand, the Philippines and Vietnam; D and $\mathrm{R}$ are the disposable and returnable packaging, given that a $30 \%$ buffer

stock of the disposables is compulsory; and the

symbols $\rightarrow$ and --> represent the flows of the packaging with products and the emptied packaging

$\underline{\text { Returnable Packaging under Round- and Multi-Trip }}$ Arrangements

Fig. 5 illustrates the annual requirements of the returnable packaging under the round-trip arrangement by the three trading countries. Under this arrangement, a total of 5,258 units of the disposable packaging remained in use. In the figure, TH shipped 5,148 and 34,176 units of the disposable and returnable packaging to $\mathrm{PH}$. At the same time, $\mathrm{PH}$ redeployed 3,960 units of the disposable packaging to ship goods to $\mathrm{VN}$ and required 7,800 units of the TH-originated returnable packaging to ship goods to $\mathrm{TH}$.

In addition, TH shipped 110 and 96,106 units of the disposable and returnable packaging to $\mathrm{VN}$, while VN redeployed 84 units of the disposable packaging to ship goods to $\mathrm{PH}$ and required 1,152 units of the TH-originated returnable packaging to ship goods to $\mathrm{TH}$. The unused disposable packaging at the buyer's site would be scraped while the unused returnable packaging were returned to $\mathrm{TH}$. Thus, under the round-trip returnable packaging arrangement, the requirement for the disposable packaging was $5,258(5,148+110)$ units and those for the returnable packaging under the single- and round-trip arrangements were respectively 121,330 $(26,376+94,954)$ and $8,952(7,800+1,152)$ units (Table 1). 


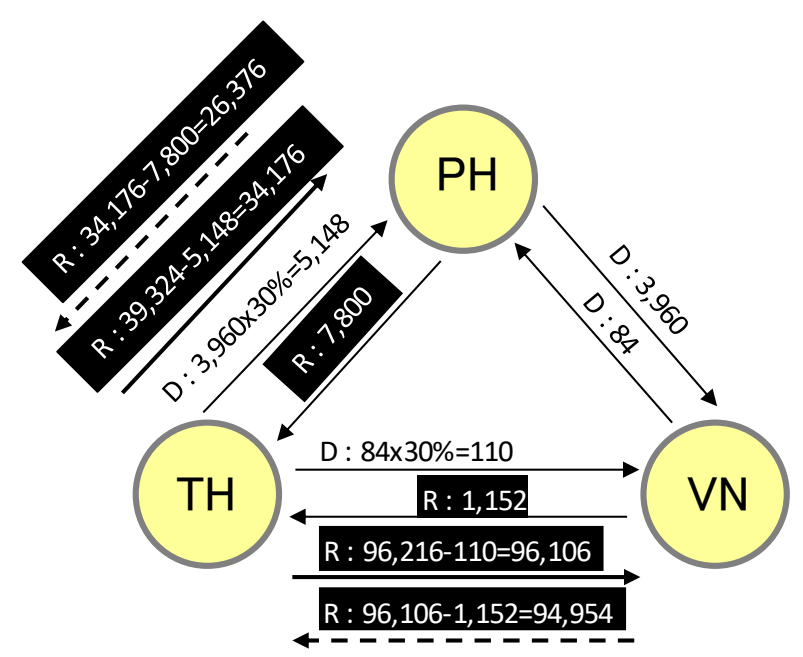

Figure.5 The annual returnable packaging requirements under the round-trip arrangement, where TH, PH and VN denote Thailand, the Philippines and Vietnam; D and R are the disposable and returnable packaging, given that a $30 \%$ buffer stock of the disposables is compulsory; and

the symbols $\rightarrow$ and --> represent the flows of the packaging with products and the emptied packaging

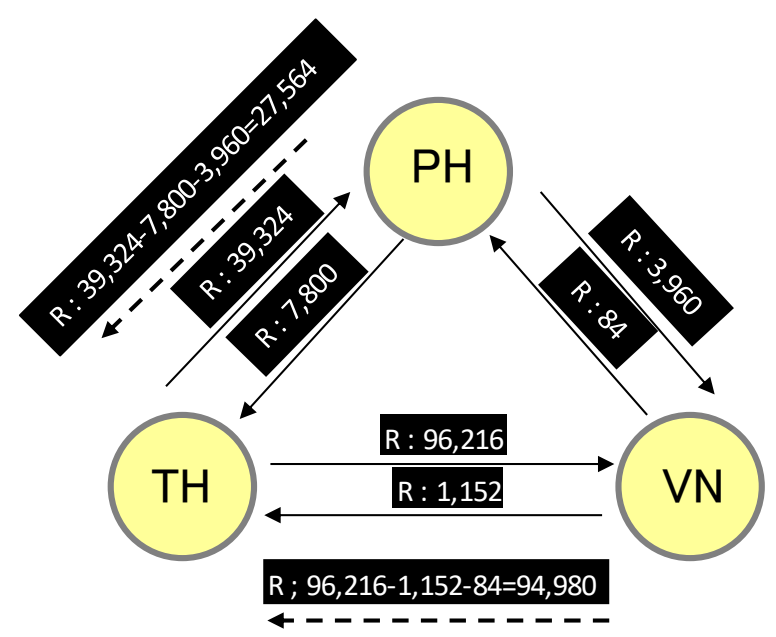

Figure.6 The annual transactions in terms of returnable packaging under the multi-trip arrangement, where $\mathrm{TH}$,

$\mathrm{PH}$ and VN denote Thailand, the Philippines and Vietnam; D and R are the disposable and returnable packaging, given that a $30 \%$ buffer stock of the disposables is compulsory; and the symbols $\rightarrow$ and --> represent the flows of the packaging with products and the emptied packaging

Fig. 6 illustrates the annual requirements of the returnable packaging under the multi-trip arrangement by the three countries. Under this arrangement, the disposable packaging requirement was completely eliminated and replaced with the returnable packaging. In the figure, $\mathrm{TH}$ shipped 39,324 units of the returnable packaging to $\mathrm{PH}$. At the same time, $\mathrm{PH}$ redeployed 7,800 and 3,960 units of the returnable packaging originally from $\mathrm{TH}$ to ship goods to $\mathrm{TH}$ and VN. In addition, TH shipped 96,216 units of the returnable packaging to $\mathrm{VN}$, while VN redeployed 1,152 and 84 units of the returnable packaging originally from $\mathrm{TH}$ to ship goods to $\mathrm{TH}$ and $\mathrm{PH}$. The unused returnable packaging were returned to $\mathrm{TH}$. Under the multi-trip returnable packaging arrangement, the requirements for the returnable packaging under the single-, round and multi-trip arrangements were respectively $122,544(2,7564+98,980) ; 8,952(7,800+1,152)$; and $4,044(3,960+84)$ units (Table 1).

Table 1. Annual packaging requirements under various logistics arrangements

\begin{tabular}{|l|r|r|r|r|r|}
\hline Logistics & \multicolumn{5}{|c|}{ Packaging volume (Units/Year) } \\
\cline { 2 - 5 } $\begin{array}{c}\text { Arrangeme } \\
\text { nt }\end{array}$ & $\begin{array}{c}\text { Disposa } \\
\text { ble }\end{array}$ & \multicolumn{3}{|c|}{ Seturnable } & Total \\
\cline { 2 - 5 } & Single & Round & Multi & \\
\hline Singosable & 135,540 & 0 & 0 & 0 & 135,540 \\
\hline Round-trip & 16,895 & 118,645 & 0 & 0 & 135,540 \\
\hline Multi-trip & 5,258 & 121,330 & 8,952 & 0 & 135,540 \\
\hline
\end{tabular}

\section{The Proposed Mathematical Model}

To determine the total effective packaging cost under the four logistics arrangements, this research has proposed a mathematical model whose notations and definitions are as follows:

$\begin{array}{llll}P_{d n} & = & \text { Total packaging cost } \\ P_{d} & = & \text { Disposable packaging cost } \\ P_{d n} & = & \text { New disposable packaging } \\ S & = & \text { Packaging scrapping cost } \\ P_{r} & = & \text { Depreciation cost of } \\ P_{r n} & = & \text { New returnable packaging } \\ & & \text { cost } \\ c & = & \text { Coefficient of capital } \\ i & = & \text { Interest rate } \\ N & = & \text { Number of depreciation } \\ & & \text { years } \\ d & = & \text { Rotation cycle } \\ D & = & \text { Number of days per year } \\ L T & = & \text { Cycle lead time } \\ I_{i} & = & \text { Importer inland cost } \\ I_{i t} & = & \text { Total importer inland cost } \\ M & = & \text { Number of returned } \\ O & = & \text { emptied packaging } \\ O_{t} & = & \text { Ocean freight cost } \\ I_{x} & = & \text { Exporter inland cost } \\ I_{x t} & = & \text { Total exporter inland cost } \\ R & = & \text { Packaging cleaning and } \\ & & \text { repairing cost } \\ & & \end{array}$


According to [24-30], the total effective packaging cost under a reverse logistics scheme entails five cost components: the disposable packaging cost, importer inland cost, ocean freight cost, exporter inland cost, and packaging cleaning and repairing cost. Nevertheless, the authors failed to discuss the calculation methods associated with these cost components. Mathematically, these five cost components can be expressed as

$$
P=P_{d}+I_{i}+O+I_{x}+R
$$

Meanwhile, this current research has identified a sixth cost component: the depreciation cost. Thus, the total effective packaging cost under reverse logistics encompasses the disposable packaging cost, depreciation cost, importer inland cost, ocean freight cost, exporter inland cost, and packaging cleaning and repairing cost.

In this research, the proposed mathematical model for the total effective packaging cost is the modified Eq. (1), whereby the depreciation cost $\left(\mathrm{P}_{\mathrm{r}}\right)$ is incorporated. The proposed model is expressed as

$$
P=P_{d}+P_{r}+I_{i}+O+I_{x}+R
$$

where $P_{d}=P_{d n}-S ; P_{r}=\frac{\left(P_{r n}\right)(c)}{d}$,

$$
\begin{aligned}
& \text { where } c=\frac{i(1+i)^{N}}{i(1+i)^{N}-1}, d=\frac{D}{L T} ; I_{i}=\frac{I_{i t}}{M} ; O=\frac{O_{t}}{M} ; \\
& \quad \text { and } I_{x}=\frac{I_{x t}}{M} .
\end{aligned}
$$

Substituting these expressions in Eq. (2) yields the proposed mathematic model for the total effective packaging cost associated with reverse logistics as

$$
\begin{aligned}
P= & \left(P_{d n}-S\right)+\left(\frac{\left(P_{r n}\right)\left(\frac{i(1+i)^{N}}{i(1+i)^{N}-1}\right)}{\frac{D}{L T}}\right)+\frac{I_{i t}}{M} \\
& +\frac{O_{t}}{M}+\frac{I_{x t}}{M}+R
\end{aligned}
$$

\section{Results and discussion}

\subsection{Numerical calculation}

The proposed mathematical model (Eq.(3)) was

\begin{tabular}{|c|c|c|}
\hline$i$ & $=$ & $4 \%$ \\
\hline$N$ & $=$ & 6 years \\
\hline$D$ & $=$ & 365 days \\
\hline$L T$ & $=$ & $\begin{array}{l}56 \text { days (for the single-trip } \\
\text { arrangement) }\end{array}$ \\
\hline$L T$ & $=$ & $\begin{array}{l}88 \text { days (for the round-trip } \\
\text { arrangement) }\end{array}$ \\
\hline$L T$ & $=$ & $\begin{array}{l}124 \text { days (for the multi-trip } \\
\text { arrangement) }\end{array}$ \\
\hline$I_{i t}$ & $=$ & $\begin{array}{l}\text { 332.31 USD /40-foot } \\
\text { container }\end{array}$ \\
\hline$M$ & $=$ & 128 units/40-foot container \\
\hline$O_{t}$ & $=$ & $\begin{array}{l}231.60 \text { USD } / 40 \text {-foot } \\
\text { container }\end{array}$ \\
\hline$I_{x t}$ & $=$ & $\begin{array}{l}434.43 \text { USD } / 40 \text {-foot } \\
\text { container }\end{array}$ \\
\hline$R$ & $=$ & 14.31 USD /unit \\
\hline
\end{tabular}
used to determine the total effective packaging costs under the four logistics arrangements and the results presented in Table 2. The parametric values were as follows (Source: Toyota Motor Thailand):

$$
\begin{array}{lll}
P_{d n} & = & 80.89 \mathrm{USD} / \text { unit } \\
S & = & 9.43 \mathrm{USD} / \text { unit } \\
P_{r n} & = & 184.00 \mathrm{USD} / \text { unit }
\end{array}
$$

Table 2. Total effective packaging costs under the four logistics arrangements

\begin{tabular}{|l|r|r|r|r|r|r|r|}
\hline \multirow{2}{*}{$\begin{array}{c}\text { Logisti } \\
\text { cs } \\
\begin{array}{c}\text { Arrang } \\
\text { ement }\end{array}\end{array}$} & $P_{d}$ & $P_{r}$ & $I_{i}$ & $O$ & $I_{x}$ & $R$ & Total \\
\hline $\begin{array}{l}\text { Dispos } \\
\text { able }\end{array}$ & 71.46 & 0 & 0 & 0 & 0 & 0 & 71.46 \\
\hline $\begin{array}{l}\text { Single } \\
\text { trip }\end{array}$ & 0 & 5.41 & 2.57 & 1.83 & 3.51 & 14.31 & 27.63 \\
\hline $\begin{array}{l}\text { Round } \\
\text { trip }\end{array}$ & 0 & 8.47 & 2.57 & 1.83 & 3.51 & 14.31 & 30.69 \\
\hline $\begin{array}{l}\text { Multi } \\
\text { trip }\end{array}$ & 0 & 11.92 & 2.57 & 1.83 & 3.51 & 14.31 & 34.14 \\
\hline
\end{tabular}

In Table 2, under the disposable packaging (nonreverse) arrangement, only the disposable packaging cost $\left(P_{d}\right)$ constituted the total packaging cost. Under the three reverse logistics arrangements (the single-, round- and multi-trip arrangements), the total effective packaging cost consisted of the depreciation cost $\left(P_{r}\right)$, importer inland cost $\left(I_{i}\right)$, ocean freight cost $(O)$, exporter inland cost $\left(I_{x}\right)$ and packaging cleaning and repairing cost $(\mathrm{R})$. Due to the shortest cycle lead time $(L T)$ of the single-trip arrangement, its depreciation cost $\left(P_{r}\right)$ was lowest (USD 5.41), in comparison with that of the roundtrip (USD 8.47) and multi-trip arrangements (USD 11.92).

\subsection{Annual packaging cost}

Based on the annual packaging requirements under the four logistics arrangements (Table 1), Table 3 compares the annual total packaging costs and the cost reduction (\%), in relation to the disposable packaging arrangement. In the table, the multi-trip returnable packaging was the cheapest to implement with the total cost of 3.80 million 
USD/year, representing a $61 \%$ cost reduction over the disposable packaging scheme (9.69 million USD/year).

\subsection{Payback period}

Table 4 tabulates the payback periods of the four logistics arrangements. By comparison, the singletrip returnable packaging required the least number of new returnable packaging $(9,142$ units), resulting in the shortest payback period of 0.33 year.

\subsection{Packaging waste}

Table 5 tabulates the annual packaging waste under the four logistics arrangements. By comparison, the multi-trip returnable packaging produced the lowest packaging waste and was thus most environmentally-friendly. The total packaging waste under the multi-trip arrangement was $2,371,950 \mathrm{Kg} / \mathrm{year}$, representing a decrease of $68 \%$ over the disposable packaging scheme.

Table 3. Annual total packaging costs under the four logistics arrangements

\begin{tabular}{|l|r|r|r|r|r|r|}
\hline \multirow{2}{*}{$\begin{array}{c}\text { Logistic } \\
\mathrm{s}\end{array}$} & \multicolumn{5}{|c|}{ Packaging cost (Million USD/Year) } & \multicolumn{2}{c|}{$\begin{array}{c}\text { Cost } \\
\text { Arrange } \\
\text { ment }\end{array}$} & $\begin{array}{c}\text { Disp } \\
\text { osabl } \\
\mathrm{e}\end{array}$ & \multicolumn{2}{|c|}{ Returnable } & Total & $\begin{array}{c}\text { Redu } \\
\text { ction }\end{array}$ \\
\cline { 3 - 6 } & & Single & $\begin{array}{c}\text { Roun } \\
\mathrm{d}\end{array}$ & Multi & & \\
\hline $\begin{array}{l}\text { Disposa } \\
\text { ble }\end{array}$ & 9.69 & 0 & 0 & 0 & 9.69 & \\
\hline $\begin{array}{l}\text { Single- } \\
\text { trip }\end{array}$ & 1.20 & 3.29 & 0 & 0 & 4.49 & $54 \%$ \\
\hline $\begin{array}{l}\text { Round- } \\
\text { trip }\end{array}$ & 0.37 & 3.34 & 0.29 & 0 & 4.00 & $59 \%$ \\
\hline $\begin{array}{l}\text { Multi- } \\
\text { trip }\end{array}$ & 0 & 3.37 & 0.29 & 0.14 & 3.80 & $61 \%$ \\
\hline
\end{tabular}

Table 4. The payback periods under the four logistics arrangements

\begin{tabular}{|l|r|r|}
\hline \multicolumn{1}{|c|}{$\begin{array}{c}\text { Logistics } \\
\text { Arrangement }\end{array}$} & $\begin{array}{c}\text { Returnable packaging } \\
\text { investment (units) }\end{array}$ & \multicolumn{2}{c|}{$\begin{array}{c}\text { Payback } \\
\text { Period (Year) }\end{array}$} \\
\hline Disposable & 0 & - \\
\hline Single-trip & 9,142 & 0.33 \\
\hline Round-trip & 22,819 & 0.72 \\
\hline Multi-trip & 24,193 & 0.73 \\
\hline
\end{tabular}

Table 5. Packaging waste comparison

\begin{tabular}{|l|r|r|r|r|}
\hline \multirow{2}{*}{$\begin{array}{c}\text { Logistics } \\
\text { Arrangeme } \\
\text { nt }\end{array}$} & \multicolumn{2}{|c|}{$\begin{array}{c}\text { Packaging waste }(\mathrm{Kg} / \text { Year) } \\
\text { e }\end{array}$} & $\begin{array}{c}\text { Waste } \\
\text { reducti } \\
\text { on }\end{array}$ \\
\hline Disposable & $7,454,700$ & 0 & $7,454,700$ & \\
\hline Single trip & 929,225 & $2,076,288$ & $3,005,513$ & $60 \%$ \\
\hline Round trip & 289,190 & $2,279,935$ & $2,569,125$ & $65 \%$ \\
\hline Multi trip & 0 & $2,371,950$ & $2,371,950$ & $68 \%$ \\
\hline
\end{tabular}

\subsection{Environmental impact assessment}

In this research, the life cycle assessment (LCA) technique was applied to the disposable and returnable packaging (from cradle to grave) to evaluate their respective environmental impacts and identify the more environmentally-friendly option.

In the LCA analysis, the GaBi software was first used to model the life cycles of both packaging schemes and then the CML2001 method was applied to evaluate the life cycle environmental impacts ([23]). The environmental impact categories included the abiotic depletion potential (ADP), acidification potential (AP), photochemical ozone creation potential (POCP), eutrophication potential (EP), ozone layer depletion potential (ODP) and global warming potential (GWP).

The LCA primary data were the material types and actual weights of the disposable and returnable packaging. The LCA secondary data were the emissions associated with both packaging schemes from the European technology processes database embedded in the GaBi software.

The analysis assumptions of the disposable packaging scheme were: The DE: Steel sheet PE process in the $\mathrm{GaBi}$ database represented the life cycle of the metallic frame of the disposable packaging (55 Kg in weight); the carton pads and the kola tape were excluded from the LCA analysis due to the data unavailability; and the paper identification label was also excluded due to the duplicity as the label was also used in the returnable packaging scheme. Meanwhile, under the returnable packaging, the DE: Steel sheet PE" process was assumed to represent the life cycle of the metallic frame and four metal plates, whose total weight (105 $\mathrm{Kg}$ ) was divided by the packaging lifetime.

Fig. 7 illustrates the environmental impact assessment by six environmental impact categories. The results showed that the returnable packaging was more environmentally-friendly due to the considerably lower environmental impacts, relative to the disposable packaging. The greater environmental impacts of the disposable packaging were largely attributable to their single use vis-à-vis the multiple uses of the returnable packaging. Importantly, further improvements could still be made to the returnable packaging to reduce the environmental impacts; for instance, the metallic frame could be replaced with a more environmentally-friendly, lighter alternative. 


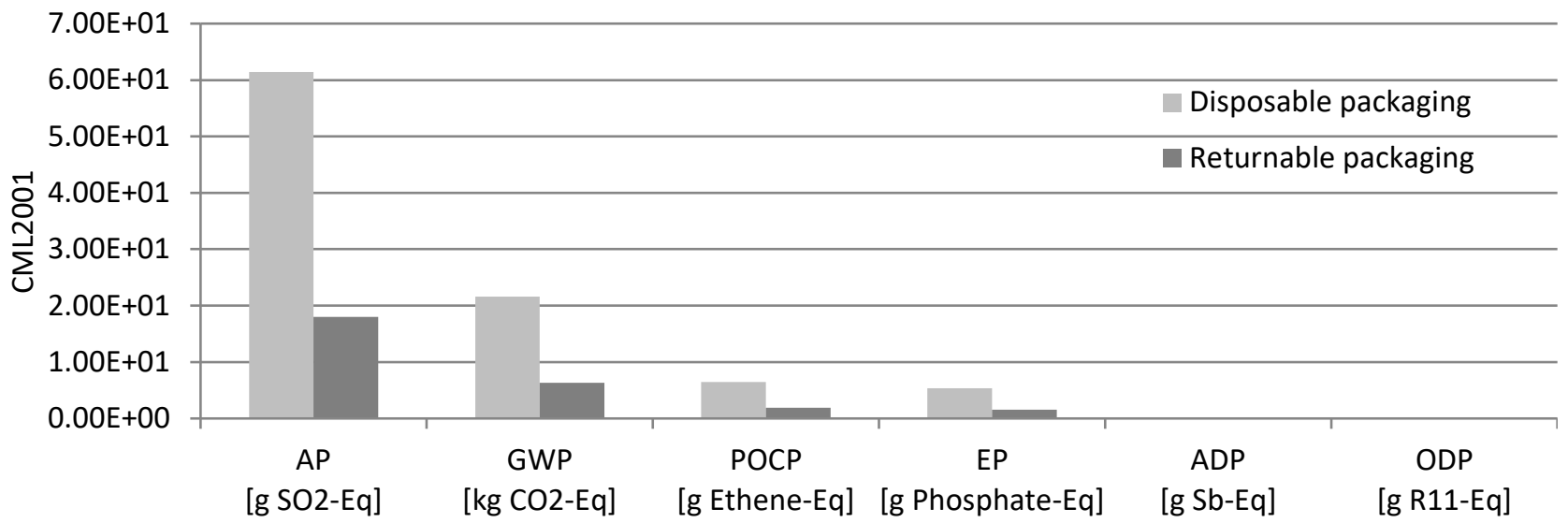

Figure.7 The LCA of the disposable and returnable packaging by the environmental impact categories

\section{Conclusions and implications}

This research has investigated the operational, economic and environmental benefits of the returnable packaging under various reverse logistics arrangements. The business of interest was a Thailand-based auto-parts manufacturer and exporter with the trading partners in the Philippines and Vietnam. In the study, a switch was made from the currently disposable packaging to the standardized returnable packaging under three reverse logistics arrangements: the single-, roundand multi-trip arrangements. Due to the large initial investment of the returnable packaging, a mathematical model was proposed to calculate the total effective packaging cost. Moreover, the life cycle assessment (LCA) was applied to the disposable and returnable packaging to evaluate their respective environmental impacts throughout their lifetime.

The findings revealed that the switch contributed to the lower demand for the disposable packaging and the packaging cost reduction. The strengthened steel structure also offered better product protections. The numerical results indicated that the multi-trip reverse logistics arrangement achieved the largest total packaging cost reduction and packaging waste reduction of $61 \%$ and $68 \%$, respectively, in comparison with the disposable packaging. Meanwhile, the single-trip reverse logistics arrangement exhibited the shortest payback period (0.33 year) as a result of the smallest initial investment and shortest cycle lead time. The life cycle assessment (LCA) with regard to the ADP, AP, POCP, EP, ODP and GWP associated with both packaging schemes identified the returnable packaging as the more environmentally-friendly option due to the significantly lower environmental impacts.
In fact, the implementation of the round- and multi-trip reverse logistics arrangements requires extra care in the handling of returnable packaging to minimize the damage to the packaging. The extra care requirement burdens the warehouse operators and assembly workers. In addition, some countries classify the returnable packaging as a finished product, thus subjected to the customs duties or taxation. Furthermore, the need for the returnable packaging to travel long distances and the specific characteristics of the materials required for producing the packaging may lead to situations where the disposable packaging becomes more environmentally preferable. Thus, both the economic and environmental considerations of the returnable packaging should be taken into account prior to the implementation.

Notwithstanding, future research should examine the application of a tracking system to returnable packaging to identify the location and estimated time of arrival. Moreover, attempt should be made to replace the metallic frame with another strong but lightweight material since the metallic frame is heavy and thus accounts for the largest proportion of the total weight of the packaging. A lightweight substitute material would contribute considerably to a lower transportation cost.

\section{References}

[1] E.B. Mariano, J.A. Gobbo, F.C. Camioto, and D.A.N. Rebelatto, "CO2 Emissions and Logistics Performance: A Composite Index Proposal", Journal of Cleaner Production, pp. 1-13, 2016.

[2] V. Ravi and E. Shankar, "Analysis of Interactions among the Barriers of Reverse Logistics", Technological Forecasting \& Social Change, Vol.72, pp. 1011-1029, 2005. 
[3] J. Garcia-Arca, A.T.G. Garrido, and J.C. PradoPrado, "Packaging Logistics for Improving Performance in Supply Chains: The Role of Meta-Standards Implementation", Production, Vol.26, pp. 261-272, 2016.

[4] P.L. Gonzalez-Torre, B. Adenso-Díaz, and H. Artiba, "Environmental and Reverse Logistics Policies in European Bottling and Packaging Firms", International Journal of Production Economics, Vol.88, pp. 95-104, 2004.

[5] M.P. Brito and R. Dekker, "A Framework for Reverse Logistics", ERIM Report Series Reference, no. ERS-2003-045-LIS, Erasmus Research Institute of Management (ERIM), 2003.

[6] D.S. Rogers and R.S. Tibben-Lembke, "Differences between Forward and Reverse Logistics in a Retail Environment", Supply Chain Management, Vol.7, pp. 271-282, 2002.

[7] K.S. Khor and Z.M. Udin, "Impact of Reverse Logistics Product Disposition towards Business Performance in Malaysian E\&E Companies", Journal of Supply Chain Customer Relationship Management, pp. 1-19, 2012.

[8] C. Bai and J. Sarkis, "Flexibility in Reverse Logistics: A Framework and Evaluation Approach", Journal of Cleaner Production, Vol.47, pp. 306-318, 2013.

[9] C.H. Glock, "Decision Support Models for Managing Returnable Transport Items in Supply Chains: A Systematic Literature Review", International Journal of Production Economics, Vol.183, pp. 561-569, 2016.

[10] J. Ostlin, E. Sundin and M. Bjorkman, "Product Life-Cycle Implications for Remanufacturing Strategies", Journal of Cleaner Production, Vol.17, pp. 999-1009, 2009.

[11] V. Jayaraman and Y. Luo, "Creating Competitive Advantages through New Value Creation: A Reverse Logistics Perspective", Academy Management of Perspective, Vol.21, pp. 56-73, 2007.

[12] S. Dowlatshahi, "The Role of Transportation in the Design and Implementation of Reverse Logistics Systems", International Journal of Production Research, Vol.48, pp. 4199-4215, 2010.

[13] M. Bernon and J. Cullen, "An Integrated Approach to Managing Reverse Logistics", International Journal of Logistics Research and Applications, Vol.10, pp.41-56, 2007.

[14] C.R. Carter and L.M. Ellram, "Reverse Logistics: A Review of the Literature and Framework for Future Investigation", Journal Business Logistics, Vol.19, pp. 85-102, 1998.
[15] J. Xu，X. Jian, and Z. Wu, "A Sustainable Performance Assessment Framework for Plastic Film Supply Chain Management from a Chinese Perspective". Sustainability, Vol.8, pp. 1042-1065, 2016.

[16] Y. Dae Ko, I. Noh, and H. Hwang, "Cost Benefits from Standardization of the Packaging Glass Bottles", Computers \& Industrial Engineering, Vol.62, pp. 693-702, 2011.

[17] B.R. Cobb, "Inventory Control for Returnable Transport Items in a Closed-loop Supply Chain", Transportation Research Part E, Vol.86, pp. 53-68, 2016.

[18] J. Dethloff, "Vehicle Routing and Reverse Logistics: The Vehicle Routing Problem with Simultaneous Delivery and Pick-up", $O R$ Spectrum, Vol.23, pp. 79-96, 2001.

[19] M.R. Shaharudin, K. Govindan, S. Zailani, and K.C. Tan, "Managing Product Returns to Achieve Supply Chain Sustainability: An Exploratory Study and Research Propositions", Journal of Cleaner Production, Vol.101, pp. 1$15,2015$.

[20] R. Abubakr and P. Patel, "Packaging System Decision Making; To Assure Cost Efficient Transports", Jonkoping University, Sweden, 2016.

[21] R. Duhaime, D. Riopel, and A. Langevin, "Value Analysis and Optimization of Reusable Containers at Canada Post", Interfaces, Vol.31, pp. 3-15, 2001.

[22] S. Pokharel and A. Mutha, "Perspectives in Reverse Logistics: A Review", Resource, Conservation and Recycling, Vol.53, pp. 175182, 2009.

[23] D.A. Silva, G.W. Reno, G. Sevegnani, T.B. Sevegnani, and O.M. Truzzi, "Comparison of Disposable and Returnable Packaging: A Case Study of Reverse Logistics in Brazil", Journal of Cleaner Production, Vol.47, pp. 377-387, 2013.

[24] H. Palsson, C. Finnsgard, and C. Wanstrom, "Selection of Packaging Systems in Supply Chains from a Sustainability Perspective: The Case of Volvo", Packaging Technology and Science, Vol.26, pp. 289-310, 2016.

[25] W.V. Uxa, "Returnable/Reusable Containers in the Automotive Industry and the Related Capital Budgeting Investment”. Michigan State University, USA, 1994.

[26] W.V. Rosenau, D. Twede, M.A. Mazzeo, and S.P. Singh, "Returnable/Reusable Logistical Packaging: A Capital Budgeting Investment Decision Framework", Journal of Business Logistics, Vol.17, pp. 139-165, 1996. 
[27] S.E. Kibler, "Returnable/Reusable Logistical Packaging: A Decision Support Framework and Modular Furniture Case Study", Michigan State University, USA, 1997.

[28] M. Levi, S. Cortesi, C. Vezzoli, and G. Salvia, "A Comparative Life Cycle Assessment of Disposable and Returnable Packaging for the Distribution of Italian Fruit and Vegetables", Packaging Technology and Science, Vol.24, pp. 387-400, 2011.

[29] P. Menesatti, E. Canali, G. Sperandio, G. Burchi, G. Devlin, and C. Costa, "Cost and Waste Comparison of Reusable and Disposable Shipping Containers for Cut Flowers", Packaging Technology and Science, Vol.25, pp. 203-215, 2012.

[30] Q. Zhang, A. Segerstedt, Y. Tsao, and B. Liu, "Returnable Packaging Management in Automotive Parts Logistics: Dedicated Mode and Shared Mode", International Journal Production Economics, Vol.168, pp. 234-244, 2015.

[31] H. Williams, F. Wikstrom, and M. Lofgren, "A Life Cycle Perspective on Environmental Effects of Customer Focused Packaging Development", Journal of Cleaner Production, Vol.16, pp. 853-859, 2008.

[32] J. Laso, M. Margallo, P. Fullana, A. Bala, C. Gazulla, A. Irabien, and R. Aldaco, "Introducing Life Cycle Thinking to Define Best Available Techniques for Products: Application to the Anchovy Canning Industry", Journal of Cleaner Production, pp. 1-12, 2016.

[33] L. Garcia-Duranona, R. Farreny, and P. Navarro, "Life Cycle Assessment of a Coniferous Wood Supply Chain for Pallet Production in Catalonia", Spain, Journal of Cleaner Production, Vol.1377, pp. 178-178, 2016.

[34] R. Iannone, S. Miranda, S. Riemma, and I.D. Marco, "Improving Environmental Performances in Wine Production by a Life Cycle Assessment Analysis". Journal of Cleaner Production, Vol.111, pp. 172-180, 2016. 